\title{
Metabolic Resistance Mechanisms of Different Pesticides in The Two-Spotted Spider Mite, Tetranychus urticae Koch (Tetranychidae:Acari)
}

\author{
Salwa, E. Negm", A. A. Saleh", A. A. Abd El-Hady ${ }^{*}$, \\ H. A. Bekheat ${ }^{* *}$ and Rania A. Abd El-Wahab" \\ "Pesticide Dept., Faculty of Agriculture ,Mansoura Univ. \\ ** Plant Protection Research Institute,Dokki,Giza, E-mail: rppri@aol.com
}

\begin{abstract}
An investigation was performed to determine the possible role of detoxification metabolism in resistant strains of Tetranychus urticea Koch.Adult females were subjected to selection pressure through 40 generations by LC50's and LC90's of Vertimec (Avermectines), Cypermethrin (Pyrethroids), Methomyl (Carbamates) and Malathion (O.P), were (41.308, 42.021, 44.881, and 49.265 folds) and (49.815,55.411,63.972 and 90.00 folds), respectively, whereas RRS slopes ranged from 0.884 to 1.395 folds. Comparative assay with esterases (EST) and mixed function oxidases(MFO) showed that LC50's of Mal-Resistant strains had higher EST. activiy (4.71) with lower MFO activity (3.80),while ,LC50's of Vert-Rresistant strains had lower EST. activiy (2.70) with higher MFO activity (4.26). Synergist experiments showed low synergism by S,S,S tributylphosphorotrithioate (DEF) of EST activiy ranged from 4.81 to 2.99 folds, while synergism by Piperonyl Butoxide (PBO) of MFO activity ranged from 4.27 to 3.82 folds to $\mathrm{LC}_{50}$ 's pesticides resistant strains.
\end{abstract}

Key Words: Tetranychus urticae, Resistance, Selection Pressure, Avermectines, Pyrthroids, Carbamates OP's, Mixed Function Oxidases, Esterases, PBO, DEF

\section{INTRODUCTION}

Resistance to pesticides is conferred by genes controlling penetration, detoxification and sensitivity of the target protein (Brown, 1990). However, linkage relationships among these genes are not defined in most agricultural pests, especially mites. The two-spotted spider mite, Tetranychus urticae Koch (Acari: Tetranychidae), a worldwide pest of many plant species, after having been exposed to many pesticides for many years has developed resistance to a wide range compounds. This resistance may develop quickly because of the mite has numerous annual generations and high frequency of spray applications. The evolution of resistance depends on gene flow among populations that colonize different habitats in many places (Tsagkarakou et al., 1996).

Metabolic resistance is the potential of pests to expel poisonous pesticides from their body through chemically driven deterioration. Three enzyme systems have been found to be involved in this resistance mechanism: Nonspecific esterases, mixed function oxidases and glutathione- $\mathrm{S}$-transferases (GSTs) (Brogdon \& McAllister, 1998). A considerable amount of evidence shows that esterases are connected with acaricide resistance in many spider mite strains. Kim et al. (2004) obtained resistant strains of $T$. urticae by sequential assortment with the acaricides: carbophenothion, ethion, dicofol, cyxehation and bifenthrin, and separated easterase isoenzyme by polyacrylamide gel electrophoresis. Therefore, it was able to detect different isoenzymes in the resistant and susceptible strains. The difference indicated that esterases are associated with the resistance mechanisms of the tested acaricides.Comparing with Vertimec resistance which resulted mainly from oxidative metabolism in many pests such as Colorado potato beetles (Argentine et al., 1992), that a high resistance to abamectin resulted from increased cytochrome P-450 monooxygenase-mediated detoxification in the resistant strains. However, general esterases and carboxylesterase activities in the abamectin-resistant strains were significantly enhanced compared with the SS strain (Clark et al. ,1992).This result was most apparent in the carboxylesterase assay, which gave greater than two fold increase in hydrolyic activity to $\alpha$-naphthyl butyrate in both abamectin -resistant strains compared with the SS strain. In Vertimec resistant strains of T.urticae, the effects of the synergists were evaluated in several resistant populations.PBO produced only low levels of synergism even in (S) and $(\mathrm{R})$,as shown by their synergistic ratios 0.1 and 1.7respectively, which indicated that oxidative metabolism played its role with other metabolic systems in detoxification (Clark et al.,1992).

This study aimed to investigate the metabolic resistance in T. urticae adult females after selection with $\mathrm{LC}_{50}$ 's of Vertimec, Cypermethrin, Methomyl and Malathion based on changeable activity of 
esterases and mixed function oxidases (MFO) with and without synergists.

\section{MATERIALS AND METHODS}

\section{Pesticides and Chemicals:}

The formulated pesticides used for leaf-dip bioassays were vertimec (Averrmectines) 1.8\% EC from Syngenta Co.,cypermethrin(Pyrethroids) 50\% EC from KZ Co., methomyl (Carbamates) 90\%EC from KZ Co. and malathion (Organophosphates) 95\%EC from KZ Co.

\section{Maintenance of Tetranychus urticae:}

Colonies of the spider mite, T. urticae were reared under laboratory conditions $\left(25 \pm 2^{\circ} \mathrm{C}\right.$, and $60 \pm 5 \% \mathrm{RH})$ at Plant Protection Research Institute branch, Dakahlia Governorate. They were reared on clean castor oil plants leaves placed on moist cotton wool pad in Petri-dishes .The colonies began with mites which were taken from infested castor oil plant leaves, then left for one year under lab. Conditions to get a homogenous and sensitive colonies.

\section{Assessment of acaricidal activity:}

In this respect, laboratory experiments were conducted to evaluate the activity of tested pesticides against $T$. urticae adult females. The leafdip technique described by Dittrich (1962) was used. Mortality percentages were determined and corrected by using Abott's formula (1925) and stastically analyzed according to Finney (1971) to estimate $\mathrm{LC}_{50}, \mathrm{LC}_{90}$ and slope values.

\section{Rearing of T.urticae colonies under pesticides selection pressure: \\ Treated mite colonies were reared under selection pressure of tested pesticides, Vertimec; Cypermethrin; Methomyl and Malathion. It was carried out by leaf-dip technique at $\mathrm{LC}_{50}$ level of each of the tested toxicants, from parent's generation till $40^{\text {th }}$ generation. For studying the levels of resistance in these selected strains ,toxicity lines of each acaricide against the adult females were established every two generations. All the results of the selected strains were compared with those of the laboratory susceptible strain to calculate the level of resistance for each compound.}

\section{Estimation of esterases activity:}

EST activity was measured using $\alpha$-Naphthyl The slope of concentration-mortality lines for Acetate ( $\alpha$-NA) by the method of Van Asperen (1962) susceptible and resistant populations varied from with slight modifications .The reaction mixture $4.20 \pm 0.53$ to $5.86 \pm 0.14$, respectively, with $\mathrm{RR}=1.395$ contained $450 \mu \mathrm{l}$ of potassium phosphate buffer folds, suggesting heterozygosity in adult females in (4mM,PH 6.8) and $50 \mu \mathrm{l}$ of enzyme solution (from each population till gain resistant $40^{\text {th }}$ generation.
$0.01 \mathrm{gm}$ of each stored sample) was incubated at $37^{\circ} \mathrm{C}$ for $15 \mathrm{~min}$ after addition of $0.5 \mathrm{ml}$ of $\alpha$-NA in ethanol.The reaction was stopped and color developed by adding $0.5 \mathrm{ml}$ of dye solution $\left(10 \mathrm{glitre}^{-1}\right.$ diazoblue $\mathrm{B}$ salt $+50 \mathrm{~g}$ litre $^{-1}$ sodium lauryl sulfate) $2: 5$ by volume for $20 \mathrm{~min}$. The absorbance was read at $600 \mathrm{~nm}$ for $\alpha$-NA by a Gilford 260PS spectrophotometer.

\section{Estimation of oxidases assay:}

MFO activity was measured using p-nitroanisoleO-demethylation by the method of Kim et al., (2004). The reaction mixture contained $50 \mu 1$ of miocrosomal preparation (5-50 protein equivalents), 50 of NADPHgenerating system (Magnesium chloride $12 \mathrm{mM}$, NADPH $2.7 \mathrm{mM}$, NADP $8.1 \mathrm{mM}$, glucose-6-phosphate $240 \mathrm{Mm}$, glucose-6-phosphate dehydrogenase 25 units $\left.\mathrm{ml}^{-1}\right), 390 \mu \mathrm{l}$ of potassium buffer $(0.1 \mathrm{M}, \mathrm{PH}=7.4)$ and $10 \mu 1$ of PNA in ethanol $(0.05 \mathrm{mM})$. The reaction at $400 \mathrm{~nm}$ by a Gilford 260PS spectrophotometer. The concentration of P-nitrophenol generated was

\section{Synergism Test:}

Piperonyl Butoxide (PBO-Technical product from Sigma, Milwaukee, WI) and S,S,S tributylphosphorotrithioate (DEF-Technical product from ChemServices West Chester, PA) were used to inhibit detoxification mechanisms by esterases (EST) and mixed-function oxidses (MFO), respectively, by adding $10 \mu \mathrm{l}$ of synergist to the mite homogenates in a final concentration of $10^{-7} \mathrm{M}$ and was incubated for $5 \mathrm{~min}$ at $27^{\circ} \mathrm{C}$.

\section{RESULTS AND DISCUSSION}

The $\mathrm{LC}_{50 \text { 's }}$ and $\mathrm{LC}_{90 \text { 's }}$ for all resistant T. urticae adult females till $40^{\text {th }}$ generation, were considerably higher, and revealed large differences comparable with those of the reference strains.

\section{Vertimec Resistance:}

For the selection pressure by vertimec through 40 generations of $T$. urticae adult females, table (1) showed that $\mathrm{LC}_{50}$ and $\mathrm{LC}_{90}$ with upper and lower limits were 2099.38 (5941.245-741.830 ppm) and 7192.297 (20354.201-2541.448 ppm), respectively, which were significantly higher than susceptible strain. was run at $37^{\circ} \mathrm{C}$ for $3 \mathrm{~min}$. Absorbance was measured determined from a standard curve. 
Table (1): Development of resistance in Tetranychus urticae to Vertimec.

\begin{tabular}{|c|c|c|c|c|c|c|c|c|c|}
\hline \multirow{2}{*}{ G. } & \multicolumn{3}{|c|}{$\mathrm{LC}_{50}(\mathrm{ppm})$} & \multicolumn{3}{|c|}{$\mathrm{LC}_{90}(\mathrm{ppm})$} & \multirow{2}{*}{ Slope } & \multicolumn{2}{|c|}{ Toxicity index } \\
\hline & Main & U.L. & L.L & Main & U.L. & L.L & & $\mathrm{LC}_{50}$ & $\mathrm{LC}_{90}$ \\
\hline S. & 50.822 & 111.30 & 23.206 & 144.38 & 316.192 & 65.613 & 4.20 & 100 & 100 \\
\hline F2 & 70.416 & 147.874 & 33.531 & 523.894 & 1100.178 & 249.473 & 3.14 & 70.17 & 27.56 \\
\hline F4 & 218.763 & 437.526 & 109.382 & 998.145 & 1996.29 & 499.073 & 2.79 & 23.23 & 14.46 \\
\hline F6 & 599.431 & 1192.868 & 301.222 & 2014.333 & 4008.523 & 1012.228 & 3.01 & 8.48 & 7.17 \\
\hline F8 & 714.379 & 1500.196 & 324.718 & 3520.141 & 7392.296 & 1676.258 & 3.24 & 7.11 & 4.10 \\
\hline F10 & 825.794 & 2064.485 & 330.318 & 4199.375 & 10498.438 & 1679.75 & 3.57 & 6.15 & 3.44 \\
\hline F20 & 1032.119 & 2745.437 & 384.631 & 5210.413 & 13859.699 & 1958.802 & 4.23 & 4.92 & 2.77 \\
\hline F30 & 1571.245 & 4415.199 & 559.162 & 6031.157 & 16947.551 & 2146.319 & 5.09 & 3.23 & 2.39 \\
\hline $\mathrm{F} 40$ & 2099.38 & 5941.245 & 741.830 & 7192.297 & 20354.201 & 2541.448 & 5.86 & 2.42 & 2.00 \\
\hline
\end{tabular}

Table (2): Resistance ratios of Vertimec resistant adult females of Tetranychus urticae till $40^{\text {th }}$ generation.

\begin{tabular}{|c|c|c|c|c|c|c|c|}
\hline \multirow{2}{*}{ G. } & \multicolumn{3}{|c|}{$\mathrm{LC}_{50}$} & \multicolumn{3}{|c|}{$\mathrm{LC}_{90}$} & \multirow{2}{*}{$\begin{array}{c}\mathrm{RR} \\
\text { Slope } \\
\end{array}$} \\
\hline & RR50 & RR50 U.L. & RR50 L.L & RR90 & RR90 U.L & RR90 L.L & \\
\hline S. & -------- & ------ & ------ & ------- & ------ & ------ & ----- \\
\hline F2 & 1.386 & 1.329 & 1.44 & 3.629 & 3.479 & 3.802 & 0.748 \\
\hline F4 & 4.304 & 3.931 & 4.714 & 6.913 & 6.314 & 7.606 & 0.664 \\
\hline F6 & 11.795 & 10.718 & 12.98 & 13.952 & 12.677 & 15.427 & 0.717 \\
\hline F8 & 14.056 & 13.479 & 13.993 & 24.381 & 23.379 & 25.548 & 0.771 \\
\hline F10 & 16.249 & 18.549 & 14.234 & 29.086 & 33.203 & 25.601 & 0.85 \\
\hline F20 & 20.309 & 24.67 & 16.575 & 36.088 & 43.833 & 29.854 & 1.007 \\
\hline F30 & 30.917 & 39.67 & 24.956 & 41.773 & 53.599 & 32.712 & 1.212 \\
\hline F40 & 41.308 & 53.38 & 31.967 & 49.815 & 64.373 & 38.734 & 1.395 \\
\hline
\end{tabular}

Table (3): Development of resistance in Tetranychus urticae to Cypermethrin.

\begin{tabular}{|c|c|c|c|c|c|c|c|c|c|}
\hline & \multicolumn{3}{|c|}{$\mathrm{LC}_{50}(\mathrm{ppm})$} & \multicolumn{3}{|c|}{$\mathrm{LC}_{90}(\mathrm{ppm})$} & \multirow{2}{*}{ Slope } & \multicolumn{2}{|c|}{ Toxicity index } \\
\hline & Main & U.L. & L.L & Main & U.L. & L.L & & $\mathrm{LC}_{50}$ & $\mathrm{LC}_{90}$ \\
\hline S. & 70.356 & 148.451 & 33.344 & 175.242 & 369.761 & 83.053 & 3.71 & 100 & 100 \\
\hline F2 & 90.197 & 200.237 & 40.629 & 591.146 & 1312.344 & 200.282 & 3.52 & 78.00 & 29.64 \\
\hline F4 & 219.185 & 515.085 & 93.27 & 992.535 & 2332.457 & 422.355 & 3.03 & 32.1 & 17.66 \\
\hline F6 & 435.753 & 1050.165 & 180.81 & 1299.247 & 3131.185 & 539.107 & 3.10 & 16.15 & 13.49 \\
\hline F8 & 612.133 & 1530.333 & 244.853 & 3216.366 & 8040.915 & 1286.456 & 2.27 & 11.49 & 5.45 \\
\hline F10 & 841.385 & 2238.084 & 316.310 & 5317.977 & 14145.819 & 1999.24 & 2.98 & 8.36 & 3.3 \\
\hline F20 & 1197.196 & 3352.149 & 427.57 & 6430.032 & 17752.09 & 2264.297 & 4.07 & 5.88 & 2.76 \\
\hline F30 & 2030.175 & 5745.395 & 717.376 & 7163.215 & 20271.898 & 2531.171 & 4.13 & 3.47 & 2.45 \\
\hline F40 & 2956.44 & 889.32 & 985.48 & 9710.337 & 29131.011 & 3236.779 & 4.45 & 2.38 & 1.80 \\
\hline
\end{tabular}

Table (4): Resistance ratios of Cypermethrin resistant adult females of Tetranychus urticae till 40th generation.

\begin{tabular}{cccccccc}
\hline \multirow{2}{*}{ G. } & \multicolumn{9}{c}{ LC $_{50}$} & & & LC 90 & & RR \\
\cline { 2 - 6 } & RR50 & RR50 U.L. & RR50 L.L & RR90 & RR90 U.L & RR90 L.L & Slope \\
\hline S. & -------- & ------ & ----- & ------ & ------ & ------ & ---- \\
\hline F2 & 1.282 & 1.349 & 1.218 & 3.373 & 3.549 & 2.411 & 0.949 \\
\hline F4 & 3.115 & 3.47 & 2.797 & 5.664 & 6.308 & 5.411 & 0.817 \\
\hline F6 & 6.194 & 7.074 & 5.423 & 7.414 & 8.468 & 6.491 & 0.836 \\
\hline F8 & 8.701 & 10.309 & 7.343 & 18.354 & 21.746 & 15.491 & 0.612 \\
\hline F10 & 11.959 & 15.076 & 9.486 & 30.346 & 38.257 & 24.072 & 0.803 \\
\hline F20 & 17.016 & 22.581 & 12.823 & 36.179 & 48.01 & 27.263 & 1.097 \\
\hline F30 & 28.856 & 38.702 & 21.514 & 40.876 & 54.824 & 30.477 & 1.113 \\
\hline F40 & 42.021 & 59.7 & 29.555 & 55.411 & 78.783 & 38.972 & 1.199 \\
\hline
\end{tabular}


Table (5): Development of resistance in Tetranychus urticae to Methomyl.

\begin{tabular}{|c|c|c|c|c|c|c|c|c|c|}
\hline \multirow{2}{*}{ G. } & \multicolumn{3}{|c|}{$\mathrm{LC}_{50}(\mathrm{ppm})$} & \multicolumn{3}{|c|}{$\mathrm{LC}_{90}(\mathrm{ppm})$} & \multirow{2}{*}{ Slope } & \multicolumn{2}{|c|}{ Toxicity index } \\
\hline & Main & U.L. & L.L & Main & U.L. & L.L & & $\mathrm{LC}_{50}$ & $\mathrm{LC}_{90}$ \\
\hline S. & 140.617 & 295.296 & 66.960 & 401.599 & 803.198 & 191.238 & 3.90 & 100 & 100 \\
\hline F2 & 326.437 & 754.069 & 1441.315 & 985.114 & 2275.613 & 426.456 & 3.04 & 43.08 & 40.767 \\
\hline F4 & 539.332 & 1321.363 & 220.136 & 1423.773 & 3488.244 & 581.132 & 2.99 & 26.07 & 28.21 \\
\hline F6 & 746.543 & 1963.408 & 283.857 & 3335.146 & 8771.434 & 1268.116 & 2.76 & 18.84 & 12.04 \\
\hline F8 & 939.104 & 2554.363 & 345.259 & 5939.417 & 16155.214 & 2183.609 & 2.54 & 14.97 & 6.762 \\
\hline F10 & 1521.657 & 4428.022 & 522.906 & 8215.887 & 23908.231 & 2823.329 & 2.83 & 9.24 & 4.889 \\
\hline F20 & 3489.112 & 10467.336 & 1163.037 & 10625.143 & 31875.429 & 3541.714 & 3.09 & 4.03 & 3.779 \\
\hline F30 & 5114.725 & 15906.795 & 1644.606 & 11725.462 & 36466.187 & 3770.245 & 3.43 & 2.75 & 3.425 \\
\hline F40 & 6310.97 & 20195.104 & 1941.837 & 25691.159 & 82211.781 & 8028.487 & 3.52 & 2.23 & 1.563 \\
\hline
\end{tabular}

Table (6): Resistance ratios of Methomyl resistant adult females of Tetranychus urticae till $40^{\text {th }}$ generation.

\begin{tabular}{|c|c|c|c|c|c|c|c|}
\hline \multirow{2}{*}{ G. } & \multicolumn{3}{|c|}{$\mathrm{LC}_{50}$} & \multicolumn{3}{|c|}{$\mathrm{LC}_{90}$} & \multirow{2}{*}{$\begin{array}{c}\mathrm{RR} \\
\text { Slope } \\
\end{array}$} \\
\hline & RR50 & RR50 U.L. & RR50 L.L & RR90 & RR90 U.L & RR90 L.L & \\
\hline S. & -------- & ------- & ------ & ------- & ------- & ------- & ----- \\
\hline F2 & 2.322 & 2.554 & 2.112 & 2.453 & 2.833 & 2.23 & 0.779 \\
\hline F4 & 3.835 & 4.475 & 3.290 & 3.545 & 4.343 & 3.039 & 0.767 \\
\hline F6 & 5.309 & 6.649 & 4.243 & 8.305 & 10.921 & 6.631 & 0.708 \\
\hline F8 & 6.678 & 8.650 & 5.161 & 14.789 & 20.114 & 11.418 & 0.651 \\
\hline F10 & 10.821 & 14.995 & 7.816 & 20.458 & 29.766 & 14.763 & 0.726 \\
\hline F20 & 24.813 & 35.447 & 17.385 & 26.457 & 39.686 & 18.52 & 0.792 \\
\hline F30 & 36.373 & 53.867 & 24.583 & 29.197 & 45.401 & 19.715 & 0.879 \\
\hline F40 & 44.881 & 68.389 & 29.479 & 63.972 & 102.356 & 41.982 & 0.903 \\
\hline
\end{tabular}

Table (7): Development of resistance in Tetranychus urticae to Malathion.

\begin{tabular}{|c|c|c|c|c|c|c|c|c|c|}
\hline \multirow{2}{*}{ G. } & \multicolumn{3}{|c|}{$\mathrm{LC}_{50}(\mathrm{ppm})$} & \multicolumn{3}{|c|}{$\mathrm{LC}_{90}(\mathrm{ppm})$} & \multirow{2}{*}{ Slope } & \multicolumn{2}{|c|}{ Toxicity index } \\
\hline & Main & U.L. & L.L & Main & U.L. & L.L & & $\mathrm{LC}_{50}$ & $\mathrm{LC}_{90}$ \\
\hline S. & 172.254 & 361.733 & 82.026 & 878.378 & 1844.594 & 418.275 & 3.52 & 100 & 100 \\
\hline $\mathrm{F} 2$ & 225.741 & 521.462 & 97.723 & 1315.112 & 3037.909 & 569.313 & 3.01 & 76.31 & 66.79 \\
\hline $\mathrm{F} 4$ & 546.132 & 1310.717 & 227.555 & 3741.557 & 8979.737 & 1558.982 & 2.53 & 31.54 & 23.48 \\
\hline F6 & 896.177 & 2240.443 & 358.471 & 9525.114 & 23812.785 & 3810.046 & 2.00 & 19.22 & 9.22 \\
\hline F8 & 1541.332 & 4161.596 & 570.864 & 11410.983 & 30809.654 & 4226.29 & 2.14 & 11.18 & 7.7 \\
\hline F10 & 2937.905 & 8226.134 & 1049.252 & 14998.983 & 41995.338 & 5356.548 & 2.98 & 5.86 & 5.86 \\
\hline F20 & 5001.419 & 15504.399 & 1613.361 & 39171.662 & 121432.15 & 12636.02 & 3.31 & 3.44 & 2.24 \\
\hline F30 & 6329.881 & 19749.299 & 2028.808 & 52110.339 & 162584.26 & 16702.032 & 3.43 & 2.72 & 1.69 \\
\hline F40 & 8486.113 & 25458.339 & 2828.704 & 79054.235 & 237162.71 & 26351.412 & 3.98 & 2.03 & 1.11 \\
\hline
\end{tabular}

Table (8): Resistance ratios of Malathion resistant adult females of Tetranychus urticae till $40^{\text {th }}$ generation

\begin{tabular}{cccccccc}
\hline \multirow{2}{*}{ G. } & \multicolumn{9}{c}{ LC $_{50}$} & \multicolumn{2}{c}{ LC $_{90}$} & RR \\
\cline { 2 - 7 } & RR50 & RR50 U.L. & RR50 L.L & RR90 & RR90 U.L & RR90 L.L & Slope \\
\hline S. & ------- & ------ & ----- & ---- & ----- & ----- & $-1 .-1$ \\
\hline F2 & 1.311 & 1.442 & 1.191 & 1.497 & 1.647 & 1.361 & 1.169 \\
\hline F4 & 3.171 & 3.623 & 2.774 & 4.26 & 4.868 & 3.727 & 1.391 \\
\hline F6 & 5.203 & 6.194 & 4.37 & 10.844 & 12.909 & 9.109 & 1.76 \\
\hline F8 & 8.948 & 11.505 & 6.96 & 12.991 & 16.703 & 10.104 & 1.645 \\
\hline F10 & 17.056 & 22.741 & 12.7917 & 17.075 & 22.767 & 12.806 & 1.181 \\
\hline F20 & 29.035 & 42.861 & 19.669 & 44.595 & 65.831 & 30.21 & 1.063 \\
\hline F30 & 36.747 & 54.596 & 24.734 & 59.326 & 88.141 & 39.931 & 1.026 \\
\hline F40 & 49.265 & 70.379 & 34.485 & 90.00 & 128.572 & 63.00 & 0.884 \\
\hline
\end{tabular}


Relative to the strain (S) ,the resistance ratios (RR's),showed in table (2), to vertimec were 41.308 and 49.815 folds as determined at LC50 and LC90 levels, respectively. Consequently they exhibited moderate levels of resistance (RR) $\geq 40$, according to Hayashi scale(1983).

\section{Cypermethrin Resistance:}

For the selection pressure by cypermethrin through 40 generations of $T$. urticae adult females, table (3) showed that $\mathrm{LC}_{50}$ and $\mathrm{LC}_{90}$ with upper and lower limits were 2956.44 (8869.32-985.48 ppm) and $9710.337 \quad(29131.011-3236.779 \quad \mathrm{ppm})$, respectively, which were significantly higher than susceptible strains.

The slope of concentration-mortality lines for susceptible and resistant populations varied from $3.71 \pm 0.23$ to $4.45 \pm 0.14$, respectively, with $\mathrm{RR}$ $=1.199$ folds, suggesting heterozygosity in adult females in each population till gain resistant $40^{\text {th }}$ generation.

Relative to the strain (S) ,the resistance ratios (RR's),showed in table (4), to cypermethrin were 42.021 and 55.411 folds as determined at LC50 and LC90,respectively.Thus, they exhibited moderate levels of resistance $(\mathrm{RR}) \geq 40$,according to Hayashi scale(1983).

\section{Methomyl Resistance:}

For the selection pressure by methomyl through 40 generations of $T$. urticae adult females, table (5) showed that LC50 and LC90 with upper and lower limits were 6310.97(20195.104-1941.837) ppm and 25691.159 (82211.781-8028.487 ppm), respectively, which were significantly higher than susceptible strains.

The slope of concentration-mortality lines for susceptible and resistant populations varied from $3.90 \pm 0.08$ to $3.52 \pm 0.15$, respectively, with $\mathrm{RR}=0.903$ folds, suggesting nearly heterozygosity in adult females in each population till gain resistant $40^{\text {th }}$ generation.

Relative to the strain (S) ,the resistance ratios (RR's),showed in table (6), to methomyl were 44.881 folds at $\mathrm{LC}_{50}$ level ,so it exhibited moderate levels of resistance $(\mathrm{RR}) \geq 40$.

On the other hand, RR was 85.178 folds upon $\mathrm{LC}_{90}$ level, so it exhibited high level of resistance $\mathrm{RR} \leq 160$.

\section{Malathion Resistance:}

For the selection pressure by malathion through
40 generations of $T$. urticae adult females, table (7) showed that $\mathrm{LC}_{50}$ and $\mathrm{LC}_{90}$ with upper and lower limits were 8486.113 (25458.339-2828.704 ppm) and 79054.235 (237162.71-26351.412 ppm), respectively, which were significantly higher than susceptible strains.

The slope of concentration-mortality lines for susceptible and resistant populations varied from $3.52 \pm 0.46$ to $3.98 \pm 0.72$, respectively, with $R R$ $=0.884$ folds, suggesting nearly heterozygosity in adult females in each population till gain resistant $40^{\text {th }}$ generation.

Relative to the strain (S), the resistance ratios (RR's), showed in table (8), to malathion were 49.265 folds at $\mathrm{LC}_{50}$ level, so it exhibited moderate levels of resistance (RR) $\geq 40$ According to Hayashi scale (1983).

On the other hand, RR was 90.00 folds at $\mathrm{LC}_{90}$ level, so it exhibited high level of resistance $\mathrm{RR} \leq 160$, according to Hayashi scale (1983).

\section{Esterases Activity:}

Data in table (9) referred to the changes of the rate of $\alpha$-NA hydrolysis by vertimec, cypermetrin, methomyl and malathion resistant strains and laboratory strain of $T$. urticae adult females homogenates. The data generally revealed that all tested compounds caused increasing in $\alpha$-NA hydrolysis in the tested strains in comparable with the laboratory strain. Malathion caused the highest level of increasing in $\alpha$-NA hydrolysis (6.27) $\mu \mathrm{g} / \mathrm{mite} /$ minute, followed by methomyl (4.05) $\mu \mathrm{g} / \mathrm{mite} / \mathrm{minute}$, then cypermethrin $\mu \mathrm{g} / \mathrm{mite} / \mathrm{minute}$ and finally vertimec (2.08) $\mu \mathrm{g} / \mathrm{mite} /$ minute, while the laboratory strain recorded $1.33,1.09,0.92$ and $0.77 \mu \mathrm{g} / \mathrm{mite} / \mathrm{minute}$ as the rate of $\alpha$-NA hydrolysis by malathion, methomyl, cypermethrin and vertimec, respectively.

Esterases activity of (R) populations of $\mathrm{LC}_{50 \text { 's }}$ of vertimec, cypermetrin, methomyl and malathion towards $\alpha$-NA is much higher than that of (S) in nearly $2.70,3.45,3.72$ and 4.71 folds, in the same order.

Data in table (9) referred to the changes of the rate of $\alpha$-NA hydrolysis by vertimec, cypermetrin, methomyl and malathion resistant strains and laboratory strain of $T$. urticae adult females homogenates in the presence of DEF as synergist. The data generally revealed that all tested compounds caused synergism of increasing in $\alpha$-NA hydrolysis in the tested strains in comparable with 
Table (9): Rate of $\alpha$-NA hydrolysis $\left(2.5 \times 10^{-4} \mathrm{M}\right)$ by (S) and (R) Strains homogenates of Tetranychus urticae, with and without DEF as an Synergist

\begin{tabular}{|c|c|c|c|}
\hline \multirow{2}{*}{$\begin{array}{c}\text { Tested } \\
\text { pesticides }\end{array}$} & \multirow{2}{*}{$\begin{array}{l}\text { Substrate hydrolysis } \\
\text { and enzyme activity } \\
\text { determination }\end{array}$} & \multicolumn{2}{|c|}{ Strains } \\
\hline & & S & $\mathrm{R}$ \\
\hline \multirow[t]{4}{*}{ Vertimec } & $\alpha-\mathrm{NA}$ & 0.77 & 2.08 \\
\hline & EST. A & $\begin{array}{ll}----- \\
\end{array}$ & 2.70 \\
\hline & ${ }^{* *} \alpha-\mathrm{NA}+\mathrm{DEF}$ & 0.91 & 2.72 \\
\hline & ${ }^{*}$ EST. A & $\begin{array}{ll}----- \\
\end{array}$ & 2.99 \\
\hline \multirow[t]{4}{*}{ Cypermethrin } & $\alpha-\mathrm{NA}$ & 0.92 & 3.17 \\
\hline & ${ }^{*}$ EST. A & ------ & 3.45 \\
\hline & $\alpha-\mathrm{NA}+\mathrm{DEF}$ & 1.08 & 3.98 \\
\hline & EST. A & $\begin{array}{l}----- \\
\end{array}$ & 3.69 \\
\hline \multirow[t]{4}{*}{ Methomyl } & $\alpha-\mathrm{NA}$ & 1.09 & 4.05 \\
\hline & EST. A & ------ & 3.72 \\
\hline & $\alpha-\mathrm{NA}+\mathrm{DEF}$ & 1.53 & 6.11 \\
\hline & ${ }^{*}$ EST. A & ------ & 4 \\
\hline \multirow[t]{4}{*}{ Malathion } & $\alpha-\mathrm{NA}$ & 1.33 & 6.27 \\
\hline & EST. A & - ----- & 4.71 \\
\hline & $\alpha-\mathrm{NA}+\mathrm{DEF}$ & 1.36 & 6.54 \\
\hline & ${ }^{*}$ EST. A & $\begin{array}{l}----- \\
\end{array}$ & 4.81 \\
\hline
\end{tabular}

${ }^{*}$ EST.A $=$ Esterases Activity $=$ hydrolysis of $\alpha-\mathrm{NA}$ in R Strain ${ }^{* *} \alpha-\mathrm{NA}+\mathrm{DEF}=$ Potentiation of synergist (DEF) to pesticide

Table ( 10 ): Rate of PNA hydrolysis (2.5 x 10-4 M) by (S) and (R) Strains of Tetranychus urticae homogenates, with and without PBO as an Synergist.

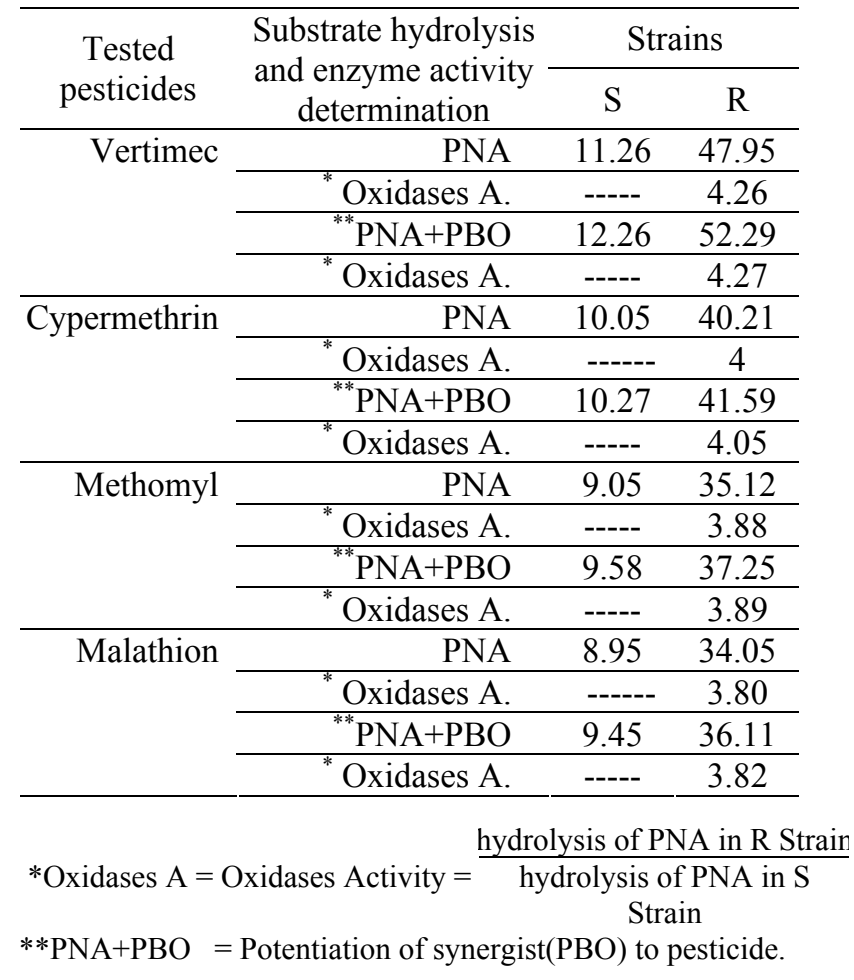

the laboratory strain.Malathion caused the highest level of increasing in $\alpha$-NA hydrolysis (6.54) $\mu \mathrm{g} / \mathrm{mite} /$ minute, followed by methomyl (6.11) $\mu \mathrm{g} / \mathrm{mite} / \mathrm{minute}$ then cypermethrin (3.98) $\mu \mathrm{g} / \mathrm{mite} / \mathrm{minute}$ and finally vertimec (2.72) $\mu \mathrm{g} / \mathrm{mite} /$ minute, while the laboratory strain recorded $1.36,1.53,1.08$ and $0.91 \mu \mathrm{g} / \mathrm{mite} / \mathrm{minute}$ as the rate of the synergism of $\alpha$-NA hydrolysis by malathion, methomyl, cypermethrin and vertimec, respectively.

Rate of $\alpha$-NA hydrolysis by (S) and (R ) strains homogenates in the presence of DEF as synergist was also measured in case of treatments with vertimec, cypermethrin, methomyl and malathion as following, 2.99, 3.69, 4.00 and 4.81 folds, in the same order.

\section{Mixed function Oxidases Activity:}

Data in table (10) referred to the changes of the rate of PNA hydrolysis by vertimec, cypermetrin, methomyl and malathion resistant strains and laboratory strain of $T$. urticae adult females homogenates. The data generally revealed that all tested compounds caused increasing in PNA hydrolysis in the tested strains in comparable with the laboratory strain.Vertimec caused the highest level of increasing in PNA hydrolysis (47.95) $\mu \mathrm{g} / \mathrm{mite} / \mathrm{minute}$,followed by cypermethrin (40.21) $\mu \mathrm{g} / \mathrm{mite} / \mathrm{minute}$ then methomyl (35.12) $\mu \mathrm{g} / \mathrm{mite} / \mathrm{minute}$ and finally malathion (34.05) $\mu \mathrm{g} / \mathrm{mite} / \mathrm{minute}$, while the laboratory strain recorded $11.26,10.05,9.05$ and $8.95 \mu \mathrm{g} / \mathrm{mite} / \mathrm{minute}$ as the rate of PNA hydrolysis by vertimec, cypermethrin, methomyl and malathion, respectively.

Mixed function oxidases activity of (R) populations of $\mathrm{LC}_{50 \text { 's }}$ of vertimec ,cypermetrin,methomyl and malathion towards PNA is much higher than that of (S) in nearly $4.26,4.00$, 3.88 and 3.80 folds in the same order.

Data in table (10) referred to the changes of the rate of PNA hydrolysis by vertimec, cypermetrin, methomyl and malathion resistant strains and laboratory strain of $T$. urticae adult females homogenates in the presence of DEF as synergist. The data generally revealed that all tested compounds caused synergism of increasing in PNA hydrolysis in the tested strains in comparable with the laboratory strain. Vertimec caused the highest level of increasing in PNA hydrolysis $(52.29) \mu \mathrm{g} / \mathrm{mite} / \mathrm{minute}$, followed by cypermethrin (41.59) $\mu \mathrm{g} / \mathrm{mite} / \mathrm{minute}$, then methomyl (37.25) $\mu \mathrm{g} / \mathrm{mite} / \mathrm{minute}$ and finally malathion (36.11) $\mu \mathrm{g} / \mathrm{mite} / \mathrm{minute}$, while the laboratory strain recorded $12.26,10.27,9.58$ and $9.45 \mu \mathrm{g} / \mathrm{mite} /$ minute as the 
rate of the synergism of $\alpha$-NA hydrolysis by malathion,methomyl,cypermethrin and vertimec, respectively.

Rate of PNA hydrolysis by (S) and (R ) strains homogenates in the presence of PBO as synergist was also measured in case of treatments with $\mathrm{LC}_{50}$ 's of vertimec, cypermetrin, methomyl and malathion as following, 4.27, 4.05, 3.89 and 3.82 folds, in the same order.

The slope of concentration-mortality line is able to indicate phenotypic variations, including environmental as well as genetic variations (Hoskins, 1960; Tabashnik and Cushing, 1989). If environmental variations in a bioassay can be constantly maintained, with errors in the estimation kept small, the slope is probably sufficient to express any relationship between slope and genetic variations in the tolerance towards a pesticide. Resistance is usually evaluated by conducting laboratory bioassays, which are typically presented as the median lethal concentration $\left(\mathrm{LC}_{50}\right)$ and slope of the concentration-mortality line (Finney, 1971).

Side by side, the resistance ratio (RR) of each acaricide was calculated by dividing the LC50 value of a treated mite population by that of strain $\mathrm{S}$. The RR's from resistant populations ranked into four categories, as suggested by Hayashi (1983); $\leq 10$, $>10$, and $\leq 40,>40$ and $\leq 160$, and $>160$, considered as low ,moderate, high and extremely high resistance, respectively. In the present study, using Hayashi scale it was found that most gained resistances ranged between moderate and high levels. Moreover, in the same trend, Shu et al. (2006) mentioned that decrease and increase in the slope suggested that the degree of heterozygosity increased and decreased over time through generations exposed to pesticides.

These results are not surprising, especially with the small number of chromosomes $(\mathrm{n}=3)$ in $T$. urticae, which increases the possibilities of multipleresistance development (Helle \& Bolland 1967). The selection with an acaricide e.g. abamectin may select populations resistant to another group of acaricides e.g. pyrethroids, if the genes responsible for resistance to these two groups are located in the same chromosome (Omoto, 1995). Abamectin resistance in T. urticae was also reported by several authors (Campos et al., 1996, Beers et al., 1998). Stumpf \& Nauen (2002), investigating enzymes involved in abamectin resistance in the two-spotted spider mite, observed that resistant strains (NL-00 and COL-00) presented several folds higher MFO (cytochrome P450-dependent monooxygenase) activity than the susceptible strain GSS. Abamectin resistance in strain NL-00 was strongly synergized by PBO (piperonyl butoxide) and DEM (diethyl maleate), suggesting that MFO and GST (glutathione S-transferases) may be involved in abamectin resistance (Stumpf \& Nauen 2002). These results are in agreement with the present results, in which vertimec resistant strains recorded higher oxidases activity than all resistant strains of other tested pesticides. It is revealed that metabolic resistance of vertimec is depending on oxidases activity levels in the treated mites. On the contrary, Chuan-hua et al. (2009) mentioned that the major resistant mechanism to abamectin in Tetranychus cinnabarinus (Boisd.) was the increasing activities of carboxylesterases (CarE) with 2.7, glutathione-Stransferase (GST) with 3.4 and mixed function oxidase (MFO) with 1.4 folds contrasted to that in susceptible strain, respectively.

Stability of acaricide resistance has been studied for several compounds in T. urticae and other species of mites (Inoue 1980, Omoto et al., 1995; Stumpf \& Nauen 2002 and Sato et al., 2004). Dicofol resistance was shown to be unstable in Panonychus citri (McGregor), in the absence of selection pressure (Inoue 1980). Lower variations in resistance frequency observed for populations with low percentage of resistant mites (Inoue 1980), corroborated the results obtained in this study with abamectin resistance in $T$. urticae. Although the abamectin resistance frequency decreased from $75 \%$ to less than $15 \%$ in six months in the population of T. urticae, abamectin resistance was shown to be stable in the laboratory at least over six months in a Dutch strain (NL-00) of two-spotted spider mite, collected from roses (Stumpf \& Nauen 2002).

Similar trends were also observed for O.P's and Carbamates but with carboxylesterases levels which were at least two times higher in $\mathrm{R}$ than $\mathrm{S}$ females, as demonstrated by several previouus studies. These results can be explained based on two major resistance mechanisms concerning this type of pesticides. Firstly, the overproduction of one of two closely related carboxylesterases (E4-FE4) that sequester or degrade organophosphates and carbamates esters before they reach their target sites in the nervous system (Foster and Devonshire, 1999). Secondly mechanism, termed MACE (Modified Acetyl Choline Esterase), due to a modification to the O.P's and Carbamates target, AChE, confers strong resistance specially to dimethylcarbamates,primicarb and triazamate.) referred to the increased esterase level in (R) strains 
because of the production of esterase isozyme that metabolises OP's.

Pyrethroids resistance associated with insensitivity of the sodium ion channel target and genetically linked to cytochrome oxidases as detoxification mechanism (Park and Brown, 2001). This explanation was proved by synergism i.e. propnylaryl ethers (Lee et al., 1999). MartinezTorres et al. (1999) explained pyrethroids resistance upon a point mutation leading to a single amino acid substitution (leucine to phenylalanine) in a voltagegated sodium channel protein that appears to be associated with resistance to several pyrethroids .It can be termed Knock-down resistance (Kdr). Concerning pyrethriods resistance, previous linkage proved that resistant cypermethrin strain showed high level of ixodases followed by resistant vertimec strain compared with other resistant strains.

\section{REFERENCES}

Abott, W. S. 1925. A method of computing effectiveness of an insecticides. J. Econ. Entomol., 18:265-267.

Argentine, J. A.; Clark, J. M. and Lin, H. 1992. Genetics and biochemical mechanisms of abamectin resistance in two isogenic strains of Colorado potato beetle. Pestic. Biochem. Physiol., 44:191-207.

Beers, E.H., Riedl, H. and Dunley, J.E. 1998. Resistance to abamectin and reversion to susceptibility to fenbutatin oxide in spider mite (Acari: Tetranychidae) populations in the Pacific Northwest. J. Econ. Entomol., 91: 352-360.

Brogdon, W. G. and McAllister, J. C. 1998. Insecticide resistance and vector control. Centers for Disease Control and Prevention, Atlanta, Georgia, USA, 4: 605-613.

Brown, T. M. 1990. Biochemical and genetic mechanisms of insecticide resistance, in Managing resistance to agrochemicals, ed by Green, M. B.; Moberg, W. K. and LeBaron, H. American Chemical Soc. Books, Washington, DC.

Campos, F., Krupa, D. A. and Dybas, R. A. 1996. Susceptibility of populations of two spotted spider mites (Acari: Tetranychidae) from Florida, Holland, and the Canary Islands to abamectin and characterization of abamectin resistance. J. Econ. Entomol., 89: 594-601.

Chuan-hua, L. H., Jin-jun, X., Ming, W., Wen-cai, L. and Zhi-mo, L. 2009. Resistance selection and biochemical mechanism of resistance to two acaricides in Tetranychus cinnabarinus
(Boisduval). Pesticide Biochem. Physiol., 93(1):47-52.

Clark, J. M., Argentine, J. A., Lin, H. and Gao, X. Y. 1992. Mechaniams of abamectin resistance in Colorado Potato beetle. In Molecular Mechanisms of Insecticide Diversity Among Insects. $1^{\text {st }}$ ed. CA. Mullins. JG Scott, 505:24763. Washington, DC:Am. Chem. Soc. Sym. Ser., 322pp.

Dittrich, V. 1962. A comparative study of toxicological test methods on a population of the two-spotted spider mite, T. urticae. J. Econ. Entomol., 55:633-648.

Finney, S. J. 1971. Probit analysis. A statistical treatment of the sigmoid response curve. $7^{\text {th }} \mathrm{Ed}$. Campridge Univ.Press, Cambridge,England.

Foster, S. P. and Devonshire, A. L. 1999. Field simulator study of insecticide resistance conferred by esterases,MACE and kdr-based mechanisms in the peach-potato aphid, Myzus persicae (Sulzer). Pestic. Sci., 55:810-814.

Hayashi, A. 1983. History, Present Status and Management of Insecticide Resistance. Pest Resistance to Pesticides .Soft Science, Tokyo, 31-53.

Helle, W. and Bolland, H. R. 1967. Karyotypes and sex determination in spider mites (Tetranychidae) Genetica, 38: 43-53.

Inoue, K. 1980. Relationship between dicofol resistance and fitness in the citrus red mite, Panonychus citri (McGregor). J. Pestic. Sci. , 5: 165-175.

Kim, Y.J.; Lee, S.H.; Lee, S.W.and Ahn ,Y.J.2004.Fenpyroximate resistance in Tetranychus urticae (Acari:Tetranychidae):crossresistance and biochemical resistance mechanisms.Pest Manag.Sci.,60(10):1001-1006.

Lee, D.; Park, Y.; Brown, T. M. and Adams, M. E. 1999. Altered properties of neuronal sodium channels associated with genetic resistance to pyrethroids. Mol. Pharmacol., 55:584-593.

Martinez-Torres, D.; Foster, S. P.; Field, L. M.; Devonshire, A. L. and Williamson, M. S. 1999. A sodium channel point mutation associated with resistance to DDT and pyrethroid insecticides in the peach potato aphid, Myzus persicae (Hemiptera:Aphididae) in 1996. Bull.Entomol. Res., 88:127-130.

Omoto, C. 1995. Resistência de Brevipalpus phoenicis (Acari: Tenuipalpidae) aos produtos químicos na citricultura, p.179-188. In C.A.L. de Oliveira \& L.C. Donadio (eds.), Leprose dos citros. Jaboticabal, FUNEP, 219pp.

Park, S. and Brown, T. M. 2001. Linkage of genes for sodium channel and cytochrome P450 
(CYP6B10) in Heliothis virescens. Pest Manag. Sci., 58:209-212.

Sato, M. E., Miyata, Da Silva T., M, Raga, A. and De Souza Filho, M. F.2004. Selections for fenpyroximate resistance and susceptibility, and inheritance, cross-resistance and stability of fenpyroximate resistance in Tetranychus urticae Koch (Acari: Tetranychidae). Appl. Entomol. Zool. , 39: 293-302.

Shu, E., Koh, S., Lee, J., Shin, K. and Cho, K. 2006. Evaluation of resistance pattern to fenpyroximate and pyridaben in Tetranychus urticae collected from greenhouses and apple orchards using lethal concentration-slope relationship. Exp. Appl. Acarol., 38:151-156.

Stumpf, N. and Nauen R. 2002. Biochemical markers linked to abamectin resistance in Tetranychus urticae (Acari-Tetranychidae). Pestic. Biochem. Physiol., 72: 111-121.

Tabashnik, B. E. and Cushing, N. L. 1989. Quantitative genetic analysis of insecticide resistance variation in fenvalerate tolerance in diamondback moth(Lepidoptera:Plutellidae) population. J. Econ. Entomol. , 82:5-10.

Tsagkarakou, A., Navajas, M., Lagnel, J., Gutierrez, J. and Pasteur, N. 1996. Genetic variability in Tetranychus urticae (Acari: Tetranychidae) from Greece: Insecticide resistance and isozymes. J. Econ. Entomol., 89:1354-1357.

Van Asperen, K. 1962. Astudy of house fly esterase by means of a sensitive colorimetric method. J. Insect Physiol., 8:401-408. 